\title{
OS SERMÕES DE QUARTA-FEIRA DE CINZA do Padre ANTÔNIO VIEIRA E A ARTE DE MORRER ESTOICO-CRISTÃ
}

http://dx.doi.org/10.11606/issn.2237-1184.v0i23p11-26

\author{
Marcelo Lachat \\ Universidade Federal do Amapá
}

RESUMO

Neste artigo, discutem-se os Sermões de Quarta-Feira de Cinza do Padre Antônio Vieira, destacando-se neles a arte estoico-cristã do saber morrer. Isso porque, nesses três sermões, centrados na passagem bíblica "és pó e em pó te tornarás" (Gênesis, 3: 19), evidenciam-se preceitos estoicos - em particular de Sêneca - mesclados à doutrina cristã, que visam, por meio de ponderações sobre a morte, pautar o comportamento dos vivos. Assim, pretende-se demonstrar que nos Sermões de Cinza de Vieira, o saber morrer é uma arte cujos preceitos devem ser aprendidos e praticados, tendo como uma de suas principais fontes a filosofia estoica. Se nessa ars, como preceitua Sêneca, "a vida toda é um aprender a morrer" (De Breuitate Vitae VII, 3-4), as agudas cinzas dos sermões de Vieira são luzes da morte e sombras da vida, sempre a lembrar: memento homo, quia pulvis es et in pulverem reverteris. Enfim, o pó é escarmento vivo e constante da morte.

\section{ABSTRACT}

In this article, the Ash Wednesday Sermons by Father Antônio Vieira are discussed, emphasising the Stoic-Christian art of knowing how to die. This is because in these three sermons, centred on the biblical passage "for dust you are and to dust you will return" (Genesis 3:19), stoic precepts are evident - particularly from Seneca - merged into Christian doctrine, which seek through considerations regarding death, to guide the behaviour of the living. Thus, it is intended to demonstrate that in the Ash Sermons by Vieira, knowing death is an art, the principles of which must be learned and practised, having stoic philosophy as one of its main sources. If in this ars, as Seneca stipulates, "The whole of life is learning to die" (De Breuitate Vitae VII, 3-4), the acute ashes from Vieira's sermons are lights of death and shadows of life, to always be remembered: memento homo, quia pulvis es et in pulverem reverteris. Finally, the dust is a living and constant chastisement of death.

PALAVRAS-CHAVE:

Letras luso-brasileiras. Séculos XVI e XVII. Padre Antônio Vieira. Sêneca.

Doutrina estoico-cristã. Arte de morrer.

\section{KEYWORDS}

Luso-Brazilian literature. 16th and 17th Centuries. Father Antônio Vieira.

Seneca.

Stoic-Christian doctrine. Art of dying. 


\section{ntrodução}

Os três Sermões de Quarta-Feira de Cinza do Padre Antônio Vieira ${ }^{1}$ desenvolvem um mesmo conceito predicável, a passagem de Gênesis em que Deus condena Adão (e, consequentemente, o ser humano em geral) à mortalidade: "tu és pó e em pó te tornarás" (Gênesis, 3: 19). Esse trecho bíblico, adequado à significação da quarta-feira de cinzas no calendário cristão, é examinado por Vieira de diferentes modos nos três sermões, mas sempre visando ao "saber morrer" enquanto arte cujos preceitos devem ser conhecidos e praticados. As lições dessa arte, de acordo com Alcir Pécora, decorrem da concepção vieiriana de morte, baseada "em extremos que supõem uma larga e difícil experiência de vida, e, afinal, propõem que o arbítrio, assaltado por sucessivos enganos, deve empregar-se na conquista de um estado de indiferença santificado e beato, fundado na disciplina da vontade".

Dessa maneira, o primeiro Sermão de Cinza, aquele pregado em Roma, na Igreja de Santo Antônio dos Portugueses, em 1672, acrescenta à mencionada passagem bíblica de Gênesis o memento homo, reforçando a constante lembrança da morte para instrução dos vivos. O que se busca esclarecer nele é uma verdade "dificultosa" (como a qualifica o próprio Vieira), para que todos aproveitem de "tão importante desengano": o homem não apenas foi e voltará a ser pó, mas o é no tempo presente, em vida; e a única diferença entre vivos e mortos é que os primeiros são pó levantado e os segundos, pó caído. Assim, o conhecimento da morte e a fé da imortalidade devem ter como efeito que "tratemos desta vida como mortais, e da outra como imortais". 3

Já o segundo Sermão de Quarta-Feira de Cinza, pregado na mesma Igreja em que o primeiro, mas um ano depois, em 1673, tem o seguinte objetivo, conforme as palavras do próprio Vieira: "Havemos de vencer um pó

\footnotetext{
${ }^{1}$ Neste trabalho, utiliza-se a primeira edição dos Sermões do Padre Vieira, atualizando-se a ortografia e a pontuação nas citações dos textos. Os dois primeiros Sermões de Quarta-Feira de Cinza estão na primeira parte, publicada em 1679, da editio princeps; já o terceiro Sermão de Cinza encontra-se na sexta parte, publicada em 1690.

2 PÉCORA, Alcir. "Saber morrer". In: Revista de História, Rio de Janeiro, v. 1, n.9, 2006, p.62.

${ }^{3}$ VIEIRA, Padre Antônio. Sermoens do P. Antonio Vieira, da Companhia de Iesu, Pregador de Sua Alteza. Primeira Parte. Lisboa: $\mathrm{Na}$ Officina de Ioam da Costa, 1679, p.133
} 
com outro pó; havemos de curar um veneno com outro veneno; havemos de matar uma morte com outra morte: a morte do pó, que havemos de ser, com a morte do pó, que somos". ${ }^{4}$ Portanto, saber morrer é ser pó por eleição, por vontade, e não apenas por necessidade; ou seja, é morrer duas vezes, é acabar a vida antes da morte para aprender, morrendo, a saber morrer. Enfim, é um aprendizado pela antecipação da morte, que não se trata de suicídio, obviamente (já que é uma prática condenada pelos cristãos), e sim de uma recusa dos negócios e gostos desta vida, deste miserável mundo. Isso porque, aqueles que antecipam a morte alcançam o paraíso terrenal e, quando morrerem fisicamente, alcançarão o céu.

No terceiro e último Sermão de Cinza, que, elaborado para a Capela Real, não teria sido pregado "por enfermidade do autor", Vieira deixa claro seu propósito: provar "que a morte, que tanto tememos, deve ser amada, e a vida, que tanto amamos, deve ser temida. E por quê? Porque (...) o pó que somos é a vida, o pó que havemos de ser é a morte; e o maior bem da vida é a morte, o maior mal da morte é a vida". ${ }^{5}$ Para atingir esse propósito, um dos principais argumentos de Vieira, retirado do Livro de Jó, é que a vida do homem é uma perpétua guerra, na qual a carne e o espírito são os inimigos. E só a morte pode acabar com essa guerra, pois é apenas por meio da morte que a alma se separa do corpo e o espírito da carne e, apartados os combatentes, tudo fica em paz. Além disso, é também a morte que põe fim ao maior mal da vida: o pecado. Por isso, para obter essa paz, é preciso viver como morto; e para viver como morto, é necessário viver com Cristo e em Deus. Como explica Vieira, enfim: "Quem vive em Deus não vive em si, quem vive com Cristo não vive com o mundo, e quem não vive em si nem com o mundo, este verdadeiramente vive como morto".

Isso posto, cabe ressaltar novamente que, neste trabalho, pretende-se mostrar que nos três referidos textos de Vieira (voltados às "cinzas"), a morte, ou melhor, o saber morrer é uma arte cujos preceitos devem ser aprendidos e praticados; uma arte que tem como uma relevante fonte a filosofia estoica em geral e, em particular, Sêneca. E não é aleatória essa relação proposta, pois os próprios Sermões de Cinza, além de apresentarem uma concepção de morte semelhante à dos estoicos, citam (todos os três), explicitamente, Sêneca, sobressaindo o filósofo cordovês como uma importante auctoritas pagã acerca da arte de morrer. É o caso, por exemplo, do sermão de 1672, que menciona

\footnotetext{
${ }^{4}$ Idem, p. 1043.

${ }^{5}$ VIEIRA, Padre Antônio. Sermoens do P. Antonio Vieira, da Companhia de Jesu, Visitador da Provincia do Brasil, Pregador de Sua Majestade. Sexta Parte. Lisboa: Na Officina de Miguel Deslandes, 1690, p.59.

${ }^{6}$ Idem, p.87.
} 
a Consolação a Márcia de Sêneca, referindo-se ao filósofo da seguinte maneira:

Morimur ut mortales, vivimus ut immortales: morreremos como mortais que somos, e vivemos como se fôramos imortais. Assim o dizia Sêneca gentio à Roma gentia. Vós a isto dizeis que Sêneca era um estoico. E não é mais ser cristão que ser estoico? Sêneca não conhecia a imortalidade da alma; o mais a que chegou foi a duvidá-la, e contudo entendia isto. ${ }^{7}$

\section{A doutrina estoico-cristã dos séculos XVI e XVII}

O excerto, citado acima, do Sermão de Cinza pregado por Vieira em 1672 é fundamental, porque suscita a questão da assimilação de preceitos estoicos na doutrina cristã. Nesse sentido, sobre a história da filosofia estoica, muito já se escreveu, e foge aos intuitos deste trabalho recontá-la ou acrescentar algo ao que já foi feito. Contudo, cabe lembrar que, desde Diógenes Laércio, repetiu-se muitas vezes a suposta origem do termo "estoico":

Zênon costumava dar as suas lições passeando de um lado para outro na Colunata Pintada (Poikile Stoâ), também chamada de Colunata de Peisiânax, mas que recebeu o seu nome por causa das pinturas de Polígnotos (o objetivo de Zênon era evitar a presença de profanos). Naquele local foram mortos mil e quatrocentos cidadãos atenienses na época dos Trinta. Lá, então, os cidadãos vinham ouvir Zênon, e por isso passaram a ser chamados estoicos; assim também foram chamados seus seguidores, que a princípio tinham o nome de zenonianos, como afirma Epícuros nas Epístolas. De acordo com Eratostenes no oitavo livro de sua obra Sobre a Comédia Antiga, a designação de estoicos tinha sido aplicada anteriormente aos poetas que passavam o tempo naquele local, tornando ainda mais famoso o nome. ${ }^{8}$

Os estoicos, assim como outros filósofos antigos, dividiram a filosofia em três partes: lógica, ética e física. Nenhuma dessas partes poderia ser separada da outra, pois estariam unidas estreitamente. $\mathrm{Na}$ repisada comparação da filosofia com um ovo, a casca seria a lógica, a clara a ética, e a gema a física; cada uma com sua função, mas formando um composto único e articulado. ${ }^{9}$ Embora as três partes da filosofia devessem compor um conjunto, a doutrina estoica foi sendo reduzida à ética (principalmente nos séculos XVI e XVII). A figura do sábio estoico, imperturbável ante as paixões,

\footnotetext{
${ }^{7}$ VIEIRA, Padre Antônio. Sermoens... Primeira parte, op.cit., p.133.

${ }^{8}$ LAÉRCIO, Diógenes. Vidas e doutrinas dos filósofos ilustres. Tradução do grego, introdução e notas de Mário da Gama Kury. $2^{\text {a }}$ ed., $2^{a}$ reimpressão. Brasília: Editora Universidade de Brasília, 2014, p.182.

${ }^{9}$ Cf. Idem, p.190.
} 
impassível frente às desgraças, é a primeira imagem que surge em grande parte dos textos que mencionam a doutrina da Stoa.

As discussões quinhentistas e seiscentistas acerca da doutrina estoica dialogam abertamente com os preceitos dos autores antigos, em especial Sêneca e Epicteto, buscando delineá-los com contornos cristãos. A importância dessa filosofia para o século XVI começou a ser pensada e discutida a partir, principalmente, do trabalho pioneiro de Léontine Zanta, intitulado La Renaissance du Stoïcisme au XVI siècle (publicado em 1914). $\mathrm{Na}$ esteira desse estudo, muitos outros sobre o tema foram publicados, cristalizando-se o termo "neoestoicismo". 10 Entretanto, neste trabalho, prefere-se utilizar a expressão "filosofia ou doutrina estoico-cristã". Isso porque, como problematiza Robert Müller, até mesmo a noção de "estoicismo" mostra-se inadequada para designar a filosofia estoica antiga: esta apenas artificialmente pode ser considerada como um "sistema", visto que sua história é muito mais aquela de seus filósofos (ou melhor, dos fragmentos que restaram deles), isoladamente, do que a sistematização de um pensamento em comum. ${ }^{11}$ Além disso, evita-se o emprego do termo "estoicismo" neste estudo, porque não se encontram ocorrências dessa palavra nos escritos dos autores quinhentistas e seiscentistas, sendo muito mais comum eles se referirem aos "estoicos" ou à "filosofia", "doutrina" ou "seita estoica". Quanto àquele termo "neoestoicismo", que a maior parte dos estudiosos do assunto costuma utilizar para nomear a retomada da filosofia estoica, se já não bastasse depender de estoicismo, parece ainda mais anacrônico e inadequado, pois ele não explica nem significa nada do que se pode verificar nas obras dos séculos XVI ou XVII. Os autores desse período não demonstram jamais se considerarem "novos estoicos", mas cristãos que têm algum interesse na doutrina estoica, e ainda menos parecem querer criar uma "escola neoestoica".

Desse modo, relendo as auctoritates antigas, os autores quinhentistas e seiscentistas foram fundamentais na divulgação dos preceitos estoicos e tiveram como um de seus principais objetivos conciliar esses preceitos com a doutrina cristã, destacando-se nomes como Justo Lípsio, Guillaume du Vair, Francisco de Quevedo e D. Francisco Manuel de Melo. Nos escritos desses

\footnotetext{
${ }^{10}$ Para ilustrar, vale referir as seguintes obras: SAUNDERS, J.L. Justus Lipsius: The Philosophy of Renaissance Stoicism. New York: The Liberal Arts Press, 1955; SPANNEUT, M. Permanence du stoïcisme de Zenon à Malraux. Bruxelles-Paris: Duculot, 1973; OESTREICHE, G. Neostoicism and the Early Modern State. Cambridge: Cambridge University Press, 1982; MORFORD, M. Stoics and Neostoics. Rubens and the Circle of Lipsius. Princeton: Princeton University Press, 1991; LAGRÉE, J. Juste Lipse et la Restauration du Stö̈cisme. Suivi de textes de Juste Lipse. Paris: J. Vrin, 1994; Le stö̈cisme au XVt et au XVII siècle: Le retour des philosophies antiques à l'âge classique. Tome I. Sous la direction de Pierre-François Moreau. Paris: Albin Michel, 1999; CARABIN, D. Les idées stö̈ciennes dans la littérature morale des XVI et XVII siècles (1575-1642). Paris: Champion, 2004; e Stoïcisme et Christianisme à la Renaissance, Cahiers V.L. Saulnier 23. Reponsable Catherine Magnien. Paris: Rue d'Ulm/Presses de l'École normale supérieure, 2006.

${ }^{11}$ Cf. MÜLLER, Robert. Les stö̈ciens : la liberté et l'ordre du monde. Paris : J. Vrin, 2006, p.11-16.
} 
autores, uma constante parece se impor: a "filosofia estoica" do período é uma doutrina estoico-cristã. Em termos cristãos, não se pode defender a apatheia, o suicídio, o Fatum, o sábio igual aos deuses (ou a Deus) etc. No entanto, isso não implica uma doutrina, filosofia ou seita antiestoica; antes, é uma clara demonstração de apropriação de ensinamentos dos antigos, inseridos num mundo cristão. É como cristãos que esses autores escrevem, mas nem por isso não escrevem como estoicos.

Contudo, é necessário ressaltar que a referida tentativa de conciliação entre a doutrina estoica e a cristã já existia nos escritos dos Padres da Igreja, como bem demonstram Léontine Zanta ${ }^{12}$ e Michel Spanneut. ${ }^{13}$ Nas palavras de Émile Bréhier, "il serait aisé de montrer par exemple que les écrivains chrétiens du III au $\mathrm{V}^{\mathrm{e}}$ siècle empruntèrent au Stö̈cisme tous les préceptes moraux qu'ils ne trouvaient pas dans les livres canoniques". ${ }^{14}$ Mencionem-se, pois, dois exemplos. Uma questão essencial no debate entre estoicos e cristãos é a noção de livre-arbítrio. Para os filósofos da Stoa, o Fatum determinaria todas as coisas que acontecem e, inclusive, as "coisas divinas". Diante disso, conforme assinala Zanta ${ }^{15}$, Santo Agostinho, refletindo sobre alguns preceitos provenientes dos estoicos, coaduna a vontade e a liberdade humanas com a presciência divina (que não está pré-determinada por nada além da própria vontade de Deus):

Non est autem consequens, ut, si Deo certus est omnium ordo causarum, ideo nihil sit in nostrae uoluntatis arbitrio. Et ipsae quippe nostrae uoluntates in causarum ordine sunt, qui certus est Deo eiusque praescientia continetur, quoniam et humanae uoluntates humanorum operum causae sunt; atque ita, qui omnes rerum causas praesciuit, profecto in eis causis etiam nostras uoluntates ignorare non potuit, quas nostrorum operum causas esse praesciuit (De Ciuitate Dei, V, IX). ${ }^{16}$

Esse problema será retomado pelos autores dos séculos XVI e XVII e será um dos pontos centrais (e mais difíceis de serem conciliados) na busca por uma harmonização entre a filosofia estoica e a cristã.

Outro ponto chave para tal coadunação será a apatheia estoica frente à esperança dos mártires cristãos. Desde Santo Agostinho (De Ciuitate Dei, V,

\footnotetext{
${ }^{12}$ ZANTA, Léontine. La Renaissance du Stoïcisme au XVle siècle. Thèse pour le Doctorat ès Lettres, présentée à la Faculté des Lettres de l'Unversité de Paris. Paris: Honoré Champion, 1914, p.99-122.

${ }^{13}$ SPANNEUT, Michel. Le stoïcisme des pères de l'Église de Clément de Rome à Clément d'Alexandrie, Paris: Seuil, 1957.

${ }^{14}$ BRÉHIER, Émile. Les Stoïciens. Textes traduits par Émile Bréhier; édités sous la direction de Pierre-Maxime Schuhl. Paris Gallimard, 1997, p. LX.

${ }^{15}$ ZANTA, Léontine. La Renaissance du Stö̈cisme au XVI siècle, op.cit., p.108.

16 "Mas pelo facto de a ordem das causas estar determinada para Deus, não se conclui que nada depende do arbítrio da nossa vontade. É que as nossas próprias vontades pertencem à ordem causal, certa para Deus e contida na sua presciência. As vontades humanas são efectivamente as causas das acções humanas, e por conseguinte aquele que previu todas as causas das coisas não pôde ignorar, entre as causas, as nossas próprias vontades, pois que previu as causas das nossas acções." (SANTO AGOSTINHO.

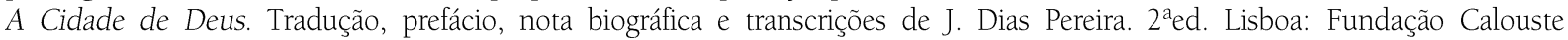
Gulbenkian, 1996, p.489)
} 
XVIII) e Tertuliano (Ad Martyres, II), por exemplo, já se discutia essa questão que afasta as doutrinas e que os estoico-cristãos tentarão resolver. Zanta resume bem o problema e também a solução daqueles "Pais da Igreja":

Ce mépris des biens extérieurs, cette constance du sage, que nous retrouvons chez le chrétien, n'est plus l'ataraxie stoïcienne, ni l'orgueilleux défi jeté à la nature humaine, ni le triomphe sans merci de la raison sur la sensibilité. Non, ce qui anime le courage des martyrs, c'est l'espérance ; ce qui permet au saint mieux qu'au sage de mépriser tous les biens de la terre, c'est l'amour de Dieu et l'assurance qu'il retrouvera d'autres biens supérieurs. ${ }^{17}$

Isso posto, cabe ressaltar que Sêneca é o estoico mais editado, traduzido e lido nos séculos XVI e XVII. A primeira edição crítica de sua Opera Omnia, como se sabe, ficou a cargo de Erasmo (Basileia, 1515). Como salienta Blüher, essa edição "se debe estimar tanto más cuanto que hasta el final del siglo XVI fue la única edición crítica que, completada y corregida, quedó disponible en el mercado del libro, también en España". ${ }^{18}$ Além disso, vale lembrar também o comentário de Calvino ao De Clementia, publicado em 1532. Das edições de Sêneca posteriores a Erasmo, podem citar-se a de Marc Antoine Muret (Roma, 1585) e aquela que é a mais importante e a mais utilizada no século XVII: a de Justo Lípsio (Antuérpia, 1605). ${ }^{19}$ Aliás, é Lípsio, humanista flamengo, o principal responsável por essa retomada da filosofia estoica, que consiste, fundamentalmente, como já mencionado, na tentativa de conciliar os preceitos estoicos com aqueles da doutrina cristã. Ainda no que diz respeito a essa ressurgência dos estoicos, e especificamente nas letras ibéricas, um dos principais nomes é o espanhol Francisco de Quevedo, que divulga e discute a filosofia estoica em diversos textos, inclusive em tratados específicos sobre ela. Num desses tratados, intitulado Nombre, origen, intento, recomendación y descendencia de la doctrina estoica (1634), Quevedo faz um interessante comentário sobre seu próprio caráter, destacando a importância dos preceitos estoicos:

\footnotetext{
${ }^{17}$ ZANTA, Léontine. La Renaissance du Stö̈cisme au XVl siècle, op.cit., p.116. "Esse desprezo dos bens exteriores, essa constância do sábio, que reencontramos no cristão, não é mais a ataraxia estoica, nem o orgulhoso desafio lançado à natureza humana, nem o triunfo sem perdão da razão sobre a sensibilidade. Não, o que anima a coragem dos mártires é a esperança; o que permite ao santo, mais do que ao sábio, desprezar todos os bens da terra é o amor de Deus e a certeza de que ele encontrará outros bens superiores". (Tradução minha).

${ }^{18}$ BLÜHER, Karl Alfred. Séneca en España: investigaciones sobre la recepción de Séneca en España desde el siglo XIII hasta el siglo XVII. Versión española de Juan Conde. Edición corregida y aumentada. Madrid: Gredos, 1983, p.235.

19 "Pero el punto culminante de esta actividad editora, que se desarrolló con extrema rapidez en el espacio de dos décadas desde 1585, lo constituyó la edición monumental, con comentarios filosóficos, de Lípsio (Amberes, 1605 y ed. posteriores), que llegó a ser la edición más importante del siglo XVII." (Idem, p.418). A respeito das edições de Sêneca a partir de 1585 e as suas traduções castelhanas, vejam-se as informações de Blüher (Idem, p.418-426).
} 
Yo no tengo suficiencia de estoico, mas tengo afición a los estoicos. Hame asistido su doctrina por guía en las dudas, por consuelo en los trabajos, por defensa en las persecuciones, que tanta parte han poseído de mi vida.

Yo he tenido su doctrina por estudio continuo; no sé si ella ha tenido en mí buen estudiante. $^{20}$

A filosofia estoico-cristã também ressoa nas práticas letradas portuguesas do século XVII, especialmente nos escritos de D. Francisco Manuel de Melo. Giacinto Manuppella ${ }^{21}$, José Adriano de Carvalho ${ }^{22}$, Segismundo Spina ${ }^{23}$ e Maria Lucília Gonçalves Pires ${ }^{24}$ já indicaram a presença marcante da filosofia dos estoicos (em particular, de Sêneca) nas obras do Melodino e a necessidade de estudos mais específicos e detalhados, ainda hoje inexistentes, acerca dessa questão. Entre as Obras Morales (publicadas em Roma, em 1664) de D. Francisco Manuel, por exemplo, há um tratado intitulado Vitoria del Hombre sobre el Combate de Virtudes y Vícios: Triunfo de la Filosofia Cristiana contra la Doctrina Estoyca. Além disso, vale lembrar que no Hospital das Letras, o mais conhecido de seus Apólogos Dialogais, dois dos personagens que participam do diálogo são justamente Lípsio e Quevedo (na verdade, são seus livros que conversam entre si), autores fundamentais da doutrina estoico-cristã, como já salientado.

Assim, observa-se que os ecos das lições estoicas não se restringem aos Sermões de Quarta-Feira de Cinza do Padre Vieira, já que também ressoam nas letras seiscentistas em geral. E neste artigo, em particular, destacam-se os relevantes ecos senequianos acerca do saber morrer nos mencionados textos de Vieira.

\section{Os Sermões de Cinza e o saber morrer estoico-cristão}

Tanto nos Sermões de Cinza vieirianos quanto em boa parte da obra de Sêneca há uma preocupação central e constante: a morte. Na filosofia senequiana, acentua-se esse tema (que já era marcante na filosofia antiga grega e latina); desse modo, em seu tratado Sobre a Brevidade da Vida, há uma lição de Sêneca a Paulino (a quem se dirige o texto) que expõe e sintetiza tal preocupação: "Deve-se aprender a viver por toda a vida e, por

\footnotetext{
${ }^{20}$ QUEVEDO, Francisco de. Obras completas. Tomo I: Obras en prosa. 6aed. Madrid: Aguilar, 1992.

${ }^{21}$ MANUPPELLA, Giacinto. "Acerca do Cosmopolitismo Intelectual de D. Francisco Manuel de Melo". Brasília, volume 11, Coimbra, p.59-76, 1961.

22 CARVALHO, José Adriano de. "A poesia sacra de D. Francisco Manuel de Melo". Arquivos do Centro Cultural Português, volume 8. Paris: Fundação Calouste Gulbenkian, p. 295-404, 1974.

${ }^{23}$ SPINA, Segismundo. "Introdução". A Tuba de Calíope. São Paulo: Brasiliense; Edusp, p. 15-21, 1988.

${ }^{24}$ PIRES, Maria Lucília Gonçalves. "O tema da «guerra interior» nas Obras Métricas de D. Francisco Manuel de Melo". Xadrez de Palavras: Estudos de Literatura Barroca. Lisboa: Cosmos, p.53-74, 1996.
} 
mais que tu talvez te espantes, a vida toda é um aprender a morrer". ${ }^{25}$ Nesse trecho, evidencia-se que a arte de viver é também uma arte de morrer, ou melhor, o bem viver depende do saber morrer. Na obra senequiana, a vida e a prática filosófica pela qual ela deve se pautar são, em última instância, uma preparação para a morte, pois o homem nasceu para morrer e a cada dia que vive se aproxima mais da morte.

Nos Sermões de Quarta-Feira de Cinza do Padre Vieira, a morte também aparece como algo inevitável e que se aproxima, constantemente, dos vivos. No fim daquele primeiro sermão (de 1672), lembra o pregador aos ouvintes: "se todos os dias podemos morrer, se cada dia nos imos chegando mais à morte, e ela a nós, não se acabe com este dia a memória da morte". ${ }^{26}$ E no início do segundo Sermão de Cinza, pregado um ano depois, retoma Vieira o primeiro, para fazer a seguinte advertência: "Assim comecei eu o ano passado, quando todos estávamos mais longe da morte; mas hoje, que também estamos todos mais perto dela, importa mais tratar do remédio, que encarecer o perigo". ${ }^{27}$ Dessa forma, esses trechos de Vieira podem ser relacionados com um lugar-comum da filosofia de Sêneca: o cotidie morimur. ${ }^{28}$ Essa recorrente expressão senequiana preceitua que o viver é um incessante morrer, isto é, que a vida é uma morte inexorável. Aceitar-se que se morre a cada dia, desde o nascimento, é eficaz consolo ou remédio para combater paixões relacionadas à morte, como o medo e a tristeza. Isso porque, pela razão, deve-se admitir que a morte é algo natural e inevitável; não admiti-lo é viver no engano, contra a natureza e contra a razão.

Sendo assim, compreende-se melhor outra citação que Vieira, no Sermão de Cinza de 1673, faz de Sêneca, mais especificamente de uma das Cartas a Lucílio (32), na qual o filósofo recomenda ao seu discípulo que, caso ele queira morrer seguro e viver o que lhe resta sem temor, acabe a vida antes da morte. ${ }^{29}$ Como já mencionado, acabar a vida antes da morte, segundo

\footnotetext{
${ }^{25}$ SÊNECA, Lúcio Aneu. Sobre a brevidade da vida. Tradução, notas e introdução de William Li. Edição bilíngue. São Paulo: Nova Alexandria, 1993. "Viuere tota uita discendum est et, quod magis fortasse miraberis, tota uita discendum est mori." (De Breuitate Vitae, VII, 3-4)

${ }^{26}$ VIEIRA, Padre Antônio. Sermoens... Primeira parte, op.cit., p.140.

${ }^{27}$ Idem, p. 1039-1040

${ }^{28}$ Para ilustrar o cotidie morimur, vale citar dois trechos das Cartas a Lucílio de Sêneca, sugeridos por Blüher (Séneca en España, op.cit., p.180), que tratam do tema: "Quem mihi dabis qui aliquod pretium tempori ponat, qui diem aestimet, qui intellegat se cotidie mori? In hoc enim fallimur, quod mortem prospicimus: magna pars eius iam praeterit. Quidquid aetatis retro est mors tenet. Fac ergo, mi Lucili, quod facere te scribis, omnes horas complectere; sic fiet ut minus ex crastino pendeas, si hodierno manum inieceris. Dum differtur vita transcurrit. Omnia, Lucili, aliena sunt, tempus tantum nostrum est." (Epistulae Morales ad Lucilium., I, 2-3); e "Cotidie morimur; cotidie enim demitur aliqua pars uitae, et tunc quoque cum crescimus uita decrescit. Infantiam amisimus, deinde pueritiam, deinde adulescentiam. Vsque ad hesternum quidquid transit temporis periit; hunc ipsum quem agimus diem cum morte diuidimus. Quemadmodum clepsydram non extremum stilicidium exhaurit sed quidquid ante defluxit, sic ultima hora qua esse desinimus non sola mortem facit sed sola consummat; tunc ad illam peruenimus, sed diu uenimus." (Idem, XXIV, 20).

29 "Quer dizer mais claramente que o remédio único contra a morte é acabar a vida antes de morrer. Este é o meu pensamento, e envergonho-me, sendo pensamento tão cristão, que o dissesse primeiro um gentio. Considera quam pulchra res sit consummare vitam ante mortem: deinde expectare securum reliquam temporis sui partem? Lucílio meu (diz Sêneca escrevendo de Roma a
} 
Vieira, não se trata, obviamente, do suicídio, condenado pelos preceitos cristãos, mas sim morrer para os negócios, gostos e bens desta vida, deste mundo miserável, para viver-se unicamente com Cristo e em Deus. Desse modo, o suicídio é um tema interessante para observar-se como são conciliados certos aspectos da filosofia estoica (isto é, de autores ditos "pagãos" ou "gentios") com a doutrina cristã. Isso porque, vale recordar que, numa das Cartas a Lucílio (70), lê-se a seguinte afirmação de Sêneca: "é preferível o suicídio mais imundo à mais higiénica servidão". ${ }^{30}$ Contudo, é preciso ressaltar que, para os estoicos, a morte voluntária não é uma fuga ou um ato irracional, e sim uma decisão racional que convém ao sábio em circunstâncias extremas, nas quais se mostre inviável uma vida digna e conforme a natureza. Em casos assim extremos, é conveniente para o sábio, num ato de liberdade, cometer o suicídio. ${ }^{31}$ E o próprio Vieira, no terceiro Sermão de Quarta-Feira de Cinza (aquele não datado, que se diz não ter sido pregado por enfermidade do autor), faz referência a essa licença dos estoicos para tirar a própria vida, devido à sua preferência pela virtude:

Muitos filósofos, e particularmente os estoicos, cuja seita, pela preferência da virtude, se avizinhava mais ao lume da razão, não só davam licença aos seus professores para que antepusessem a morte à vida, mas aos que em caso de honra tomavam por suas mãos a mesma morte (a que chamavam porta da liberdade) os introduziam por ela à imortalidade da glória. ${ }^{32}$

Essa alegada preferência dos estoicos por uma vida guiada pela virtude confirma-se nas obras de outro filósofo antigo, também auctoritas fundamental na doutrina estoico-cristã dos séculos XVI e XVII: Epicteto. A importância desse filósofo da Stoa nos anos Quinhentos e Seiscentos se comprova pelo grande número de edições e traduções de seu Encheiridon, em especial. A primeira versão latina do Encheiridon é a de Policiano, publicada em Veneza (1498); será ela a principal referência de todas as edições seguintes, pois, como afirma Léontine Zanta, "pendant près d'un demi-siècle elle servira de base à tous les traducteurs ou commentateurs

\footnotetext{
Sicília): O pensamento saiu de Roma, e fora melhor que não saísse. Lucílio meu, considera com atenção o que agora te direi, e toma um conselho que te dou como mestre e como amigo. Se queres morrer seguro, e viver o que te resta sem temor, acaba a vida antes da morte. Ó grande e profundo conselho, merecedor verdadeiramente de melhor autor, e digno de ser abraçado de todos os que tiverem fé e entendimento! Consumare vitam ante mortem: Acabar a vida antes de morrer, e ser pó por eleição, antes de ser pó por necessidade. Isto disse e ensinou um homem gentio, porque para conhecer esta verdade não é necessário ser cristão; basta ser homem: Memento homo." (VIEIRA, Padre Antônio. Sermoens... Primeira parte, op.cit., p.1045-1046).

${ }^{30}$ SÊNECA, Lúcio Aneu. Cartas a Lucílio. Tradução, prefácio e notas de J. A. Segurado e Campos. $5^{a}$ edição. Lisboa: Fundação Calouste Gulbenkian, 2014, p.269.

${ }^{31}$ Cf. KOUTLOUKA, 1987, apud PIRATELI, Marcelo Augusto; MELO, José Joaquim Pereira. "A morte no pensamento de Lúcio Aneu Sêneca." In: Acta Scientiarum. Human and Social Sciences, Maringá, v. 28, n. 1, 2006, p.69.

${ }^{32}$ VIEIRA, Padre Antônio. Sermoens... Sexta Parte, op.cit., p.63.
} 
d'Épictète". 33 Em 1535, também em Veneza, Victor Trincavelli adicionará ao Manual de Epicteto a primeira edição das Diatribes. Numerosas são as traduções posteriores, podendo ser mencionadas a de Hieronymus Wolf (1563), a de Guillaume du Vair (por volta de 1585), cujo "prefácio" é a primeira versão da Philosophie morale des stoïques, e a de Francisco Sánchez de las Brozas, Dotrina del estoico filósofo Epicteto (Salamanca, 1600), considerada por Blüher "el primer documento de importancia del Neoestoicismo en España". 34 Outras duas traduções espanholas do Encheiridon merecem ser citadas: a de Gonzalo Correas (Salamanca, 1630) e, especialmente, a tradução em verso de Francisco de Quevedo, Epicteto y Phocilides (1635), bastante dependente da versão de Sánchez de las Brozas.

Um dos preceitos mais recorrentes e fundamentais tanto nas Diatribes como no Encheiridon de Epicteto ${ }^{35}$ é a distinção entre aquilo que está sob o controle da razão humana e aquilo que não está. O que o ser humano controla é apenas sua prohairesis: seu "propósito moral" ou sua capacidade de antecipação e escolha prévia, para que faça o uso correto das "impressões externas", das phantasias (conforme, por exemplo, Diatribes, I, 1; e Encheiridon, 1). Dessa forma, uma conduta virtuosa, para Epicteto, resumese ao sustine et abstine: é preciso negligenciar as coisas externas para que se mantenha o "propósito moral" (Encheiridon, 13); esse é o caminho que conduz à virtude e pelo qual se afasta o vício. E é justamente para isto que serve a filosofa: para a preparação, com antecedência, contra os infortúnios; trata-se de um verdadeiro "treinamento" (Diatribes, III, 10 e 12; Encheiridon, 29). Quando alguém depara com uma "impressão externa" (phantasia), não deve deixar levar-se de imediato por ela, e sim dar tempo à reflexão: só assim é possível tornar-se mestre de si mesmo (Encheiridon, 20). Nesse sentido, como sintetiza Sêneca numa de suas Cartas a Lucílio, governar a si mesmo é o maior governo que há: "imperare sibi maximum imperium est" (Ep. ad Luc., CXIII, 30).

Nas letras ibéricas do século XVII, esses (e outros) ensinamentos estoicos, mesclados à doutrina cristã, difundem-se entre diversos autores, particularmente, como já referido, nos escritos de Francisco de Quevedo (que, inclusive, como mencionado anteriormente, fez uma tradução em verso do Encheiridon, de Epicteto). No trecho que encerra o capítulo I do tratado La cuna y la sepultura: para el conocimiento proprio y desengaño de las cosas ajenas (pela dedicatória, sabe-se que esse escrito data de 1633; porém, sua

\footnotetext{
${ }^{33}$ ZANTA, Léontine. La Renaissance du Stoïcisme au XVle siècle, op.cit., p.139.

${ }^{34}$ BLÜHER, Karl Alfred. Séneca en España, op.cit., p.370.

35 EPICTETO. The Discourses as reported by Arrain, the Manual, and Fragments. 2v. With an English translation by R.D. Hicks. Cambridge, Mass.; London: Harvard University Press, 1998.
} 
primeira edição é de 1634), Quevedo cristianiza o cotidie morimur senequiano bem como a distinção de Epicteto entre as coisas próprias e as alheias, advertindo, assim, que o único cuidado que se deve ter é com a alma (própria e imortal) e não com o corpo (alheio e perecível):

Empieza, pues, hombre, con esto conocimiento, y ten de ti firmemente tales opiniones: que naciste para morir y que vives muriendo; que traes el alma enterrada en el cuerpo, que cuando muere, en cierta forma resucita; que tu negocio es el logro de tu alma; que el cuerpo sirve a esa vida prestada que gastas; que es tan frágil como ves, tan perecedero como parece y que es más feo que parece, y que en breve tiempo lo estará más; que tu cuidado es tu alma, y que solas sus cosas son tuyas, y las demás ajenas; que no debes trabajar en otras, sino en ésas, por estar a tu cargo; que has de dar cuenta dellas al que te las dio y que se las agradeces sólo con dársela buena; y que el premio o el castigo se te aguarda a ti; y que pues será forzoso morir para ti, y a tu riesgo, es razón que vivas para ti, y a tu provecho. ${ }^{36}$

No primeiro Sermão de Cinza, aquele pregado em 1672, Vieira igualmente adverte que "todos nascemos para morrer, e todos morremos para ressuscitar". Por isso, deve-se temer não a morte, mas a imortalidade:

Senhores meus, não seja isto cerimônia: falemos muito seriamente, que o dia é disso. Ou cremos que somos imortais, ou não. Se o homem acaba com o pó, não tenho que dizer; mas se o pó há de tornar a ser homem, não sei o que vos diga, nem o que me diga. A mim não me faz medo o pó que hei de ser; faz medo o que há de ser o pó. Eu não temo na morte a morte, temo a imortalidade; eu não temo hoje o dia de Cinza, temo hoje o dia de Páscoa, porque sei que hei de ressuscitar, porque sei que hei de viver para sempre, porque sei que me espera uma eternidade, ou no Céu, ou no Inferno.

Assim, nesse trecho, há uma cristianização do cotidie morimur de Sêneca, adicionando-se à certeza da morte a crença na imortalidade. Segundo Vieira, então, viver não é apenas um incessante morrer, mas temer, nesta vida perecível, o que virá depois da morte: a ressurreição para a vida eterna, a ser desfrutada no céu ou sofrida no inferno. Nessa lição vieiriana, está implicada, portanto, a doutrina do bem morrer, tendo em vista a imortalidade (no céu ou no inferno) que a todos aguarda. Contudo, como se lê no segundo Sermão de Cinza (1673), a morte é única, não havendo chance de errar; dessa forma, ela não tem remédio depois, mas somente antes. Diferentemente do nascer, em que todos são iguais e não há possibilidade de erro, bastando, por isso, nascer uma vez, "no morrer, em que o erro ou acerto importa tudo, e há de durar para sempre, era justo que o homem pudesse

\footnotetext{
${ }^{36}$ QUEVEDO, Francisco de. Obras completas, op.cit., 1330.

${ }^{37}$ VIEIRA, Padre Antônio. Sermoens... Primeira parte, op.cit., p. 128
} 
morrer duas vezes, para eleger a morte que mais quisesse, e para aprender, morrendo, a saber morrer". 38 Se para a boa morte, aquela que visa à vida eterna no céu, é necessário aprender, morrendo, a saber morrer e se "nenhuma coisa se faz bem da primeira vez, quanto mais a maior de todas, que é morrer bem", Vieira, que afirma serem poucos os que sabem morrer, ensina aos muitos que não o sabem: "quem morre antes da morte, não há mister mais doutrina para bem morrer". 39 , para morrer-se antes da morte, ainda conforme as lições desse mesmo sermão, é preciso desenganar-se, recusando-se os negócios e gostos da vida. Isso porque:

Se nesta vida, e neste miserável mundo, cheio, para todos os estados, de tantos pesares, pode haver gosto algum puro e sincero, só os que acabam a vida antes de morrer a gozam. Para todos os outros é a vida e o mundo, vale de lágrimas; só para os que acabaram a vida antes da morte, é paraíso na terra.

Esse acabar a vida antes de morrer, que se dá pela negação dos gostos e negócios mundanos, pode ser relacionado àquele mencionado sustine et abstine atribuído a Epicteto, já embebido na doutrina cristã no sermão de Vieira: deve-se suportar os sofrimentos e abster-se dos gostos e negócios deste miserável mundo, para, morrendo em vida, alcançar-se o paraíso na terra e, após a (segunda) morte, a eternidade no céu. Para quem assim o faz, "corra o mundo por onde correr, nenhuma coisa lhe empece, nem lhe dá cuidado". São Paulo e São Bernardo são dois exempla de tal estado:

Um dos professores deste estado foi (como vimos) S. Paulo, e por isso, ainda vivo, dizia: Vivo autem, jam non ego (Gál. 2, 20). E que quer dizer: Eu vivo, mas já não sou eu? Quer dizer, diz S. Bernardo: Ad alia quidem omnia mortuus sum: non sentio, non attendo, non curo: Todas as coisas deste mundo são para mim como para os mortos; nem as sinto, nem me dão cuidado, nem faço mais caso delas, que se não foram; porque se elas ainda são, eu já não sou. ${ }^{41}$

O emprego desses dois santos no Sermão de Cinza de Vieira está de acordo com a função dos santos na doutrina cristã em geral. Como afirma Jean-Yves Tilliete, "il est bien évident que la sainteté chrétienne (...) ne se réduit pas à cette dimension magique. Le saint n'est pas (pas seulement) un medium, une force indifférenciée, un passeur entre les deux rivages du monde. Il est d'abord un individu". Mais ainda : "il faudrait parler ici de la fonction des saints comme modèles, cette fois au sens d'exemples à suivre,

\footnotetext{
${ }^{38}$ Idem, p. 1059.

${ }^{39}$ Idem, p. 1060.

${ }^{40}$ Idem, p. 1109.

${ }^{41}$ Idem, p. 1113
} 
moteurs de conversions individuelles". ${ }^{42}$ Dessa maneira, São Paulo e São Bernardo funcionam, no texto vieiriano, como modelos, como exemplos a seguir: sábios cristãos ou santos estoicos dignos de imitação. Nesse sentido, vale recordar que a infundada notícia da amizade e da troca de correspondência entre Sêneca e São Paulo era ainda bastante divulgada no século XVII, como explica Blüher:

Es cierto que el Humanismo y, en particular, Erasmo habían terminado con el mito de la amistad de Séneca con San Pablo, mito que había documentado la posición de Séneca ante el cristianismo en el Medievo. Como hemos visto, durante el siglo XVI España siguió, en la mayoría de las obras, la opinión de Erasmo. Abundan las indicaciones de que esa invención estaba a punto de disiparse. Es, pues, tanto más asombroso que vuelva a surgir en el siglo XVII, renovada y con más vitalidad que antes. $^{43}$

Assim, a revitalização, nos anos Seiscentos, do "mito" dessa suposta amizade indica que teria havido, desde o início, uma afinidade entre estoicos e cristãos e, consequentemente, entre suas doutrinas. Cristianizando Sêneca ou estoicizando São Paulo, aos dois, mortos em vida, caberia o epitáfio escolhido por Vieira, síntese da arte de morrer estoico-cristã:

O epitáfio que eu pusera a um morto destes é aquele verso de Davi:

Inter mortuos liber (SaI. 87, 6):

Entre os mortos livre. Livre dos cuidados do mundo, porque já está fora do mundo. Livre de emulações e invejas, porque a ninguém faz oposição. Livre de esperanças e temores, porque nenhuma coisa deseja. Livre de contingências e mudanças, porque se isentou da jurisdição da fortuna. Livre dos homens, que é a mais dificultosa liberdade, porque se descativou de si mesmo. Livre finalmente de todos os pesares e moléstias e inquietações da vida, porque já é morto. $^{44}$

\section{Considerações finais}

Evidencia-se, por fim, que tanto para os estoicos quanto para Vieira a morte é liberdade e a vida, com seus frágeis bens e constantes males, é cativeiro. É o que afirma Sêneca, por exemplo, em sua Consolação a Márcia,

\footnotetext{
${ }^{42}$ TILLIETE, Jean-Yves. "Introduction". In: Les fonctions des saints dans le monde occidental (III -XIIl siècle). Actes du colloque organisé par l'École française de Rome avec le concours de l'Université de Rome " La Sapienza ». Roma : École Française de Rome, 1991, p.5-6.

${ }^{43}$ BLÜHER, Karl Alfred. Séneca en España, op.cit., p.362.

${ }^{44}$ VIEIRA, Padre Antônio. Sermoens... Primeira parte, op.cit., p.1114-1115.
} 
cuja destinatária é uma importante dama da aristocracia romana que, tendo já perdido o pai e o filho mais velho, estava em excessivo luto pela morte do filho mais novo, que morrera bastante jovem. Consola, então, Sêneca a Márcia:

A morte é uma libertação de todas as dores e o término além do qual os nossos males não ultrapassam; ela nos leva de volta àquela tranquilidade, na qual jazíamos antes de nascer. [...] A morte prematura não trouxe, pois, ao teu filho, nenhum mal: pelo contrário, ela o libertou do sofrimento de todos os males. (SÊANECA, 1992, p. $54-55)^{45}$

Com uma concepção semelhante, declara Vieira, no terceiro Sermão de Cinza, num trecho já mencionado, que "o maior bem da vida é a morte, o maior mal da morte é a vida". Afirma ainda Vieira, nesse mesmo sermão, que a morte é o "verdadeiro e certo médico para todos os males" e é também "uma correção geral que emenda em nós todos os vícios". ${ }^{4}$

Nessa última definição da morte, ela é vista como uma correção dos vícios. Para poder corrigir os vícios, é preciso que a morte tenha sua preceptiva, que ensine aos vivos a arte de morrer. Assim, neste trabalho, foram destacados alguns desses preceitos do saber morrer nos Sermões de Quarta-Feira de Cinza do Padre Vieira que dialogam, explicita ou implicitamente, com a filosofia estoica (em particular, com as obras de Sêneca). Mas é pertinente ainda ressaltar que se a morte põe fim a todos os males da vida, ela não deve ser temida. Por isso, na concepção senequiana, como se lê no tratado Sobre a Brevidade da Vida, o sábio é aquele que, "quando lhe vier o último dia, (...) não hesitará em caminhar para a morte com passo firme". ${ }^{47}$ E para não se temer a morte, como também salienta o filósofo cordovês em uma de suas Cartas a Lucílio (30), é necessário pensar sempre nela. ${ }^{48}$ Os três mencionados sermões vieirianos, desenvolvendo as cinzas como metáforas, buscam justamente tornar constante a lembrança da morte, ou ainda, procuram mostrar que saber morrer é saber viver como morto. E viver como morto é viver com Cristo e em Deus, o que segundo as próprias palavras de Vieira:

\footnotetext{
45 SÊNECA, Lúcio Aneu. Cartas Consolatórias. Tradução de Cleonice Furtado de Mendonça van Raij; apresentação de Joaquim Brasil Fontes. Campinas: Pontes, 1992, p.54-55. "Mors dolorum omnium exsolutio est et finis ultra quem mala nostra non exeunt, quae nos in illam tranquillitatem in qua antequam nasceremur iacuimus reponit. (...) Nihil ergo illi mali inmatura mors attulit: omnium etiam malorum remisit patientiam." (De Consolatione Ad Marciam, XIX, 5; XX, 6).

${ }^{46}$ VIEIRA, Padre Antônio. Sermoens... Sexta Parte, op.cit., p.71 e p.90.

47 SÊNECA, Lúcio Aneu. Sobre a brevidade da vida, op.cit., p.40. "(...) quandoque ultimus dies uenerit, non cunctabitur sapiens ire ad mortem certo gradu". (De Brevitate Vitae, XI, 2).

48 "Mas devo precaver-me, não vás tu odiar tanto como a própria morte uma carta assim tão grande. Vou terminar, portanto. Quanto a ti, vai sempre pensando na morte, para a não receares nunca!" (SÊNECA, Lúcio Aneu. Cartas a Lucílio, op.cit., p.116)
} 
É estar morto a tudo o que o mundo ama, a tudo o que o mundo estima, a tudo o que o mundo venera, a tudo o que o mundo adora, a tudo o que chama honra, a tudo o que chama interesse, a tudo o que chama boa ou má fortuna; porque tudo o que é próspero ou adverso, alto ou baixo, precioso ou vil, pesado na balança da morte viva, é vaidade, é fumo, é vento, é sombra, é nada. ${ }^{49}$

Desse modo, se para Sêneca a vida toda é um aprender a morrer, as agudas cinzas dos sermões do Padre Vieira são luzes da morte e sombras da vida, sempre a lembrar que o homem foi, é e será pó. Enfim, esse pó passado, presente e futuro é escarmento vivo e constante da morte. 